\title{
INCLUSION OF LOCAL FOODS AT MENUS OF HOTELS AND RESTAURANTS OPERATING IN ADANA AND MERSIN
}

\author{
Oya Yildirim ${ }^{1}$ \\ Oya Berkay Karaca \\ A. Celil Çakici
}

\begin{abstract}
Cuisine culture of a destination has become to be an important element of attraction in tourist travels, especially in recent years. Local foods provide significant advantages for the region in destination marketing activities. Consequently, it is thought to be important for the companies to include local foods in their menus. For this reason, in this research it is aimed to evaluate if hotels and restaurants operating in Adana and Mersin has given local foods a place in their menus. As part of this aim, we had conducted semi-structured interviews with the managers of 82 businesses in total in March 2015. It is ascertained that a considerable number of businesses $(\% 81,7)$ included local foods in their menus, the mean was calculated as \%50. Besides, it was found that the most common meat dishes were; Adana kebab, grilled meatballs, liver kebab, steak tartar a-la-turca, stuffed meatballs, the soups were: thimble, tarhana, analıkızlı, ekşili köfte. Another outcome was that indigenous drinks such as haşlama and kaynar were rarely included in the menus. The research ends with the suggestion that the ratio of local foods in menus should be increased.
\end{abstract}

Key words: Local foods, hotels, restaurants, Adana and Mersin.

\section{INTRODUCTION}

Traditional foods are defined as foods that represent societies' indigenous traditional food culture which has developed for many years as a result of the mutual interaction between ecological and sociocultural environment (Evren and f., 2010, p.818; Zorba and f., 2010, p.851). Traditional foods constituting a part of traditions, history and cultural heritage are distinct explicitly from other similar foods in that: they have unique composition and features, traditional raw materials and components are used in their production, traditional methods are used in their treatment (Kolukırık and Şener, 2010, p.754). Foods that are attained through preparation of nutrients with different process and methods is a result reached with one's specific experience and effort, a development, a lifestyle and is a human-geography relationship (Köten and f., 2010, p.515). Food is one of the significant factors reflecting the culture and identity of a society (Berik and Kahraman, 2009, p. 212) and physical and cultural environment affects food culture greatly (Sitti and f., 2009, p.208).

Turkish kitchen which has developed in the are we call Anatolia where numerous civilisations emerged, settled and vanished, has a unique food tradition considered one of the three major rich kitchens of the world after a period of thousands of years both due to its ethnic and cultural heritage and its geographic features (Kan and Kaynakçı, 2009, p.268). Turkish kitchen which embodies flavours varying from region to region, has many components that can be a source for healthy nourishment with regard to its rich variety and convenience for the palatal delight (Ulusoy and Karakaya, 2010, p.527). There are a considerable number of our foods unknown in national and international platforms but known and consumed with pleasure in some parts of Turkey (Yurt and f., 2010, p.358).

\footnotetext{
${ }^{1}$ Instructor, School of Tourism and Hotel Management, Çukurova University, Bahçe-Karataş, Adana, Turkey.
} 
It was specified in research that foreign visitors want to know "Turkish Kitchen", (Sürücüoğlu and Akman 1998:52; Hassan and f., 2010b, p.971) our cuisine culture plays an important role in tourists revisiting our country and choosing a specific region (Aslan and f., 2014, f.5). However, it is seen that the importance given to the Turkish kitchen in hotels is too low in our country, that there is either no Turkish food or only döner, kebab and pide are offered in menus of these businesses (Güler, 2007, p. 25). However, rather than being affected by foreign kitchens, featuring the unique and traditional kitchens of our country/regions by hotel and restaurant staff in their workplaces will specially improve gastronomy tourism in our country (Denizer, 2008, p. 2).

Food and beverage services are the most important branch of tourism industry. In recent years, people participate actively in cultural touristic activities to taste local foods and see how they are made. This situation increases the touristic attraction of local foods (Serçeoğlu, 2014, p.37). Nowadays the importance of food and beverage culture in a region's being an attraction center is increasing more and more. The contribution of gastronomy tourism to a region helps form a sustainable tourism vision, preserve and hold the inventory of the foods made of local nutrients or substances thus preserving and developing the regional values (Deveci and f., 2013, f.33).

In our research it is aimed to evaluate hotels and restaurants operating in Adana and Mersin with regards to their inclusion of local foods in the menus. Besides, it is aimed to draw attention to the importance of local foods with regard to gastronomy tourism through specifying the perspectives of the businesses related with the region's cuisine.

\section{RESEARCH METHOD}

Framework of the research is the hotels and qualitative restaurants in Adana and Mersin cities. Although we applied to municipalities for the acquirement of the qualitative restaurant list (having alacarte and alcohol service), we obtained limited information. This situation caused uncertainty about the list and capacity of the region. We resorted to sampling and the data was collected by means of convenience sampling.

Collection of the data took place in two stages. In the first stage semi-structured interview was preferred from among qualitative data collection methods. The reason for the qualitative approach is that the researcher has a participant role, the demand for the subject to be researched in its own natural environment, ability to make an integrative approach, presenting the perceptions, consent for the data to be collected from the senior management and the flexibility of the research design (Yıldırım and Şimşek, 2008: 40; Karasar, 2011: 157). In this context, two separate forms was made about the research subject by means of literature scanning. In the first form designed as "Interview Form" there are 15 open-ended and closed-ended questions in total. Three of questions are for specifying the features of participant and the businesses and the other twelve are for specifying menus and local food inclusion situation in menus. In March 2015, the interviews made face to face with the owners, managers and sometimes kitchen specialists took place in dates and hours decided by them and in their working places. At the end of the interview period, 82 interviews took place in total. Half of these interviews were made in Adana and the other half were made in Mersin. The questions addressed to paricipants in the interviews are as follows: 
1. Do people outside of Adana/Mersin visit your business for food and beverage needs?

2. What is the rate of people visiting your business for food and beverage needs being native or foreigner?

3. How do you decide on foods and beverages in the menus of your places?

4. How often do you update your menus on average?

5. Do you include traditional/local foods in your menu?

6. How much is the revenue you get from local foods in percentage out of your total revenue?

7. Please remark how often people who visit from outside of Adana/Mersin prefer traditional/local foods?

8. Please write the five local foods people visiting from outside of Adana/Mersin prefer most.

9. Why do you include traditional/local foods in your menu?

10. Why don't you include traditional/local foods in your menu?

11. Do you think the traditional/local foods have a role in development of gastronomy tourism in the region?

12. Do you think Adana/Mersin are rich in traditional/local foods.

In the second form prepared as "Menu observation key" local foods list made up of eight main categories was included. There are 23 meat foods, 14 olive oil foods, 14 pastries, 18 appetizers, 32 desserts, 12 breakfast food, 7 drinks and 20 soups in this key. In the second stage of the research, menus of the interviewed businesses were collected and the local foods included in these menus were marked over the menu observation key. All the data collected was analysed after being transferred to computer environment.

\section{FINDINGS AND DISCUSSION}

Businesses attending in our research are half in Adana, and half in Mersin (Table 1). While 29 hotels attended in the research, we obtained information from 53 restaurants. It is observed that one fourth of the businesses have 1-5 years of life, there are $\% 30$ percentage of them between 11-20, and even one fourth of them survive more than 20 years. When we take the ages of the businesses into account, we get the impression that they are pretty experienced about foods and specially local foods. On the other hand, it also appears that people from out of town visit related cities for food and beverage and a great part of these people are local tourists. This finding confirms Serçeoğlu's (2014) statements. 
Tab. 1. Data concerning businesses attending to research

\begin{tabular}{|c|c|c|c|c|c|}
\hline Feature & Frequency & $\%$ & Feature & $\begin{array}{c}\text { Frequenc } \\
\mathbf{y}\end{array}$ & $\%$ \\
\hline City & & & Situation of visiting from out of town & & \\
\hline Adana & 41 & 50,0 & Yes & 76 & 92,7 \\
\hline Mersin & 41 & 50,0 & No & 6 & 7,3 \\
\hline Type & & & Nationality of the visitors (n:80) & & \\
\hline Hotel & 29 & 35,4 & Majority local & 55 & 68,8 \\
\hline Restaurants & 53 & 64,6 & $\begin{array}{l}\text { Local and foreigner rate is approximately } \\
\text { the same }\end{array}$ & 22 & 27,5 \\
\hline Age of business & & & Majority foreigner & 3 & 3,8 \\
\hline Less than 1 year & 8 & 9,8 & Title of the interviewee (n:80) & & \\
\hline Between $1-5$ years & 20 & 24,4 & Business owner & 10 & 12,5 \\
\hline \begin{tabular}{|l} 
Between 6-10 \\
years
\end{tabular} & 7 & 8,5 & Food and beverage manager & 9 & 11,3 \\
\hline $\begin{array}{l}\text { Between 11-15 } \\
\text { years }\end{array}$ & 15 & 18,3 & Sales manager & 3 & 3,8 \\
\hline $\begin{array}{l}\text { Between 16-20 } \\
\text { years }\end{array}$ & 9 & 11,0 & Cuisine chief & 42 & 52,5 \\
\hline More than 20 years & 22 & 26,8 & Restaurant-hotel manager & 16 & 20,0 \\
\hline
\end{tabular}

Menu specification format and update frequency in attending businesses are shown in Table 2 . According to this, almost half $(\% 47,5)$ of the businesses take customer demands into account when specifying the menu. While in $\% 40$ it is decided by the business, customer profile is being assessed in nearly one third of them. Thus, while on the one hand a customer oriented attitude is shown in businesses for specifying the menu, and on the other hand it appears that methods that take manager-business experience and intuition into account are referred to. When it comes to menu update frequency, businesses change their menu components when they feel predominantly $(\% 45)$ the need. While approximately one fifth of them make updates once in 6 months, another one fifth of business group make one update in a year. 
Tab. 2. Menu specification format and update frequency in attending businesses

\begin{tabular}{|l|c|c|l|c|c|}
\hline \multicolumn{1}{|c|}{ Feature } & $\begin{array}{c}\text { Frequenc|} \\
\mathbf{y}\end{array}$ & $\mathbf{\%}$ & \multicolumn{1}{|c|}{ Feature } & Frequency & \% \\
\hline How the menu is specified? & 12 & 15,00 & We don't make updates & 7 & 8,8 \\
\hline Center is specifying & 32 & 40,00 & Once in 6 months & 18 & 22,5 \\
\hline Business is specifying & 25 & 31,25 & Once in a year & 17 & 21,3 \\
\hline $\begin{array}{l}\text { Customer profile is taken into } \\
\text { account }\end{array}$ & 38 & 47,50 & Once in several years & 1 & 1,3 \\
\hline $\begin{array}{l}\text { Customer demand is taken into } \\
\text { account }\end{array}$ & 6 & 7,50 & When necessary & 36 & 45,0 \\
\hline $\begin{array}{l}\text { It is specified by trial and error } \\
\text { General manager and business } \\
\text { manager specifies it }\end{array}$ & 29 & 36,25 & As the competitors update & 1 & 1,3 \\
\hline
\end{tabular}

It appears that a significant part of businesses $(\% 81,7)$ include local foods in their menus. Table 3 shows the rate of local foods in menus and in total income. There are businesses that include local foods in a wide scale as much as there are those that include in a small scale. In the data set, it is calculated that inclusion rate of local foods in menus is $\% 50$ on average. Consequently, we can say that one in every two foods in the attending businesses' menus is regional. On the other hand, the rate of income generated by local foods within total income has a similar distribution as the inclusion rate. In other words, as there are those that generate low income from local foods there are also others that generates high income. Generated income from local foods on average compared to the total income is confirmed as $\% 43,27$. This shows one in every two foods is regional but this is not reflected in the generated income, contribution of the local foods to the total income is lower. It can be inferred that this situation may be related with the costs of local foods and competition. 
Tab. 3. Rate of local foods in menus and within total income

\begin{tabular}{|c|c|c|c|c|c|}
\hline $\begin{array}{c}\text { Rate of local foods in } \\
\text { menus }\end{array}$ & $\mathbf{f}$ & $\mathbf{\%}$ & $\begin{array}{c}\text { Rate of local foods income compared to } \\
\text { total }\end{array}$ & $\mathbf{f}$ & $\mathbf{\%}$ \\
\hline Less than $10 \%$ & 11 & 17,5 & Less than $10 \%$ & 13 & 20,6 \\
\hline $11-20 \%$ & 6 & 9,5 & $11-20 \%$ & 6 & 9,5 \\
\hline $21-30 \%$ & 5 & 7,9 & $21-30 \%$ & 9 & 14,3 \\
\hline $31-40 \%$ & 5 & 7,9 & $31-40 \%$ & 5 & 7,9 \\
\hline $41-50 \%$ & 6 & 9,5 & $41-50 \%$ & 6 & 9,5 \\
\hline $51-60 \%$ & 1 & 1,6 & $51-60 \%$ & 2 & 3,2 \\
\hline $61-70 \%$ & 4 & 6,3 & $61-70 \%$ & 4 & 6,3 \\
\hline $71-80 \%$ & 4 & 6,3 & $71-80 \%$ & 3 & 4,8 \\
\hline $81-90 \%$ & 12 & 19,0 & $81-90 \%$ & 8 & 12,7 \\
\hline $91-100 \%$ & 9 & 14,3 & $91-100 \%$ & 7 & 11,1 \\
\hline Total & 63 & $\begin{array}{r}100, \\
0\end{array}$ & Total & 63 & 100, \\
\hline Mean & $50,26 \%$ & Mean & $43,27 \%$ \\
\hline
\end{tabular}

$25 \%$ of customers who visit from out of town for food and beverage prefer local foods "pretty often", $\% 35$ of them prefer "often". About $\% 40$ of them "rarely" and "sometimes" shows an interest in these local foods. \%78 of business managers attending in research think that local foods are important for the development of gastronomy tourism in the region. Besides, $\% 58,5$ of the same managers think that cities of Adana and Mersin are rich of local foods.

Most preferred foods by the customers who visit Adana and Mersin for food and beverage are shown in Table 4. Accordingly, kebap, types of grills, saç kavurma and içli köfte are the most preferred ones from among meat dishes. It is noteworthy that the restaurants in Adana has a distinct superiority in these preferences. On the other hand, Mersin becomes a little more prominent in appetizers and in local desserts. 
Tab. 4. Most prefered foods by the people visiting Adana and Mersin for food and beverage

\begin{tabular}{|c|c|c|c|c|c|c|c|}
\hline $\begin{array}{l}\text { Local Food } \\
\text { Name }\end{array}$ & $\begin{array}{l}\text { Adana } \\
\text { f (\%) }\end{array}$ & $\begin{array}{c}\text { Mersin } \\
\mathbf{f}(\%)\end{array}$ & Total & $\begin{array}{c}\text { Local Food } \\
\text { Name }\end{array}$ & $\begin{array}{l}\text { Adana } \\
\text { f (\%) }\end{array}$ & $\begin{array}{c}\text { Mersin } \\
\mathbf{f}(\%)\end{array}$ & Total \\
\hline Kebap & $28(71,8)$ & $11(28,2)$ & 39 & Haydari & - & $9(100,0)$ & 9 \\
\hline Beğendik & $1(100,0)$ & - & 1 & Şakşuka & - & $4(100,0)$ & 4 \\
\hline Saç kavurma & $3(30,0)$ & $7(70,0)$ & 10 & Babagannuş & $1(16,7)$ & $5(83,3)$ & 6 \\
\hline Lahmacun & $5(100,0)$ & - & 5 & Tepsi kebab1 & - & $2(100,0)$ & 2 \\
\hline Pide & $2(100,0)$ & - & 2 & Kağgtt kebabı & - & $1(100,0)$ & 1 \\
\hline İçli köfte & $8(80,0)$ & $\begin{array}{c}2 \\
(\% 20,0)\end{array}$ & 10 & Deniz börülcesi & - & $1(100,0)$ & 1 \\
\hline Analıkızlı & $1(100,0)$ & - & 1 & Izgara çeşitleri & $9(64,3)$ & $5(35,7)$ & 14 \\
\hline Sikma & $1(100,0)$ & - & 1 & Biber dolma & $2(100,0)$ & - & 2 \\
\hline Gözleme & $1(100,0)$ & - & 1 & İmambayıld 1 & $1(100,0)$ & - & 1 \\
\hline Çökertme & $2(100,0)$ & - & 2 & Bumbar & $1(100,0)$ & - & 1 \\
\hline Kuzu incik & $4(100,0)$ & - & 4 & Fellah köftesi & $1(100,0)$ & - & 1 \\
\hline Sigara böreği & $2(100,0)$ & - & 2 & Ekşili köfte & $1(100,0)$ & - & 1 \\
\hline Kahvaltı & $1(100,0)$ & - & 1 & Güveç & - & $2(100,0)$ & 2 \\
\hline Mantı & $1(50,0)$ & $1(50,0)$ & 2 & Kerebiç & - & $2(100,0)$ & 2 \\
\hline Yüksük soup & $4(\% 80)$ & $1(\% 20)$ & 5 & Tantuni & - & $3(100,0)$ & 3 \\
\hline Ciğer & $5(83,3)$ & $1(16,7)$ & 6 & Et haşlama & - & $1(100,0)$ & 1 \\
\hline Kuşbaşı & $5(\% 83,3)$ & $1(16,7)$ & 6 & Süzme yoghurt & - & $2(100,0)$ & 2 \\
\hline Etli tava & $2(100,0)$ & - & 2 & Ezme & $1(50,0)$ & $1(50,0)$ & 2 \\
\hline Çiğ köfte & $5(62,5)$ & $3(37,5)$ & 8 & Mercimek soup & - & $2(100,0)$ & 2 \\
\hline Külbast1 & $1(100,0)$ & - & 1 & Yayla soup & - & $1(100,0)$ & 1 \\
\hline Humus & $3(16,7)$ & $15(83,3)$ & 18 & Menemen & - & $2(100,0)$ & 2 \\
\hline Tarator & - & $5(100,0)$ & 5 & Tava & $2(66,7)$ & $1(33,3)$ & 3 \\
\hline
\end{tabular}

Availability of the breakfast in menus of businesses is shown in Table 5. Accordingly, deri tulum cheese, gözleme and sıkma are the ones most encountered. These are followed by; bazlama, çökelek and turunç jam. It was seen that local breakfast components also existed in businesses. Least found breakfast foods are Sürk and Yörük cheese. Sürk being indigenous to Hatay province, it appears that it's not preferred by businesses. 
Tab. 5. Availability of breakfast foods in menus

\begin{tabular}{|l|c|c|c|l|c|c|c|}
\hline $\begin{array}{c}\text { Breakfast Food } \\
\text { Name }\end{array}$ & $\begin{array}{c}\text { Adana } \\
\mathbf{f}(\mathbf{\%})\end{array}$ & $\begin{array}{c}\text { Mersin } \\
\mathbf{f}(\mathbf{\%})\end{array}$ & Total & Breakfast Food Name & $\begin{array}{c}\text { Adana } \\
\mathbf{f}(\mathbf{\%})\end{array}$ & $\begin{array}{c}\text { Mersin } \\
\mathbf{f}(\mathbf{\%})\end{array}$ & Total \\
\hline 1. Sürk cheese & - & $1(100,0)$ & 1 & 7. Yörük cheese & $6(85,7)$ & $1(14,3)$ & 7 \\
\hline 2. S.kma & $12(70,6)$ & $5(29,4)$ & 17 & 8. Turunç jam & $9(75,0)$ & $3(25,0)$ & 12 \\
\hline 3. Bazlama & $9(69,2)$ & $4(30,8)$ & 13 & 9. Sünme cheese & $6(85,7)$ & $1(14,3)$ & 7 \\
\hline 4. Çökelek & $9(75,0)$ & $3(25,0)$ & 12 & 10. Carra cheese & $4(80,0)$ & $1(20,0)$ & 5 \\
\hline 5. Gözleme & $11(61,1)$ & $7(38,9)$ & 18 & 11. Lavaş cheese & $6(75,0)$ & $2(25,0)$ & 8 \\
\hline 6. Deri tulum cheese & $15(60,0)$ & $10(40,0)$ & 25 & $\begin{array}{l}\text { 12. Ezme-yaprak } \\
\text { cheese }\end{array}$ & $5(71,4)$ & $2(28,6)$ & 7 \\
\hline
\end{tabular}

Table 6 shows the availability of pastries in business menus. Accordingly spring rolls is the most included one out of pastries. This is followed by mant1, water heurek and findik lahmacun. These pastries that we confirmed are the most included ones in menus appear to be the most known pastries by local and foreigner tourists (Hassan and f., 2010a, p.949). Less included pastries in the menus are kaytaz heurek and katıklı bread. The reason for this is thought to be that these foods are indigenous to Hatay province.

Tab. 6. Availability of the pastries in menus

\begin{tabular}{|l|c|c|c|l|c|c|c|}
\hline Pastries Name & $\begin{array}{c}\text { Adana } \\
\mathbf{f}(\mathbf{\%})\end{array}$ & $\begin{array}{c}\text { Mersin } \\
\mathbf{f}(\mathbf{\%})\end{array}$ & Total & Pastries Name & $\begin{array}{c}\text { Adana } \\
\mathbf{f}(\mathbf{\%})\end{array}$ & $\begin{array}{c}\text { Mersin } \\
\mathbf{f ~ ( \% )}\end{array}$ & Total \\
\hline 1.Kaytaz heurek & - & $1(100,0)$ & 1 & $\begin{array}{l}8 . \text { Peynirli } \\
\text { dolama heurek }\end{array}$ & $8(72,7)$ & $3(27,3)$ & 11 \\
\hline 2. Peppered bread & $4(44,4)$ & $5(55,6)$ & 9 & 9. Katmer & $4(80,0)$ & $1(20,0)$ & 5 \\
\hline 3.Katıklı bread & - & $2(100,0)$ & 2 & $\begin{array}{l}\text { 10. Muska } \\
\text { heurek }\end{array}$ & $5(41,7)$ & $7(58,3)$ & 12 \\
\hline 4. Mant1 & $11(57,8)$ & $8(42,1)$ & 19 & 11. Spring rolls & $17(54,8)$ & $14(45,2)$ & 31 \\
\hline 5. Findık lahmacun & $8(53,3)$ & $7(46,7)$ & 15 & 12. Saç heurek & $6(75,0)$ & $2(25,0)$ & 8 \\
\hline $\begin{array}{l}\text { 6. Kiymalı dolama } \\
\text { heurek }\end{array}$ & $5(55,6)$ & $4(44,4)$ & 9 & $\begin{array}{l}\text { 13. Susamlı } \\
\text { heurek }\end{array}$ & $2(50,0)$ & $2(50,0)$ & 4 \\
\hline $\begin{array}{l}\text { 7. Ispanaklı dolama } \\
\text { heurek }\end{array}$ & $5(55,6)$ & $4(44,4)$ & 9 & $\begin{array}{l}\text { 14. Water } \\
\text { heurek }\end{array}$ & $12(66,7)$ & $6(33,3)$ & 18 \\
\hline
\end{tabular}

Table 7 shows the availability of soups in business menus. Accordingly; tarhana, düğün, yüksük, analıkızlı, ekşili köfte and erişteli green lentil soup with noodles are the most encountered ones. It was observed that local soups are primarily included in menus and are 
balanced mixes for healthy nourishment. Oğmaç, arabaşı and tutmaç are less common soups in menus of the region. Our traditional soups oğmaç, toyga and tutmaç are not known by the youth (Şanlier and f., 2010c, p.926), that is to say, sinks gradually into oblivion. On the other hand batırık, erişka and zilif soups are never included in restaurant menus.

Tab. 7. Availability of soups in menus

\begin{tabular}{|c|c|c|c|c|c|c|c|}
\hline Soup Name & $\begin{array}{l}\text { Adana } \\
\text { f (\%) }\end{array}$ & $\begin{array}{c}\text { Mersin } \\
\text { f (\%) }\end{array}$ & Total & Soup Name & $\begin{array}{c}\text { Adana } \\
\text { f (\%) }\end{array}$ & $\begin{array}{c}\text { Mersin } \\
\text { f (\%) }\end{array}$ & Total \\
\hline 1.Dul avrat soup & $3(100,0)$ & - & 3 & 11. Batırık soup & - & - & - \\
\hline 2.Toyga soup & $1(25,0)$ & $3(75,0)$ & 4 & 12. Erişka soup & - & - & - \\
\hline 3.Ekşili köfte soup & $8(80,0)$ & $2(20,0)$ & 10 & 13. Zilif soup & - & - & - \\
\hline 4.Tarhana soup & $12(85,7)$ & $2(14,3)$ & 14 & 14.Oğmaç soup & $1(100,0)$ & - & 1 \\
\hline 5.Süt soup & $2(66,7)$ & $1(33,3)$ & 4 & 15. Topalak soup & $3(60,0)$ & $2(40,0)$ & 5 \\
\hline 6.Tatar soup & $3(100,0)$ & - & 3 & 16.Yarma soup & $1(50,0)$ & $1(50,0)$ & 2 \\
\hline 7.Düğün soup & $11(84,6)$ & $2(15,4)$ & 13 & 17. Arabaş1 soup & - & $1(100,0)$ & 1 \\
\hline 8. Erişteli green lentil soup & $6(60,4)$ & $4(40,0)$ & 10 & 18.Tutmaç soup & $2(100,0)$ & - & 2 \\
\hline 9.Yüksük soup & $10(71,4)$ & $4(28,6)$ & 14 & $\begin{array}{l}\text { 19. Analıkızlı } \\
\text { soup }\end{array}$ & $6(60,4)$ & $4(40,0)$ & 10 \\
\hline 10.Un soup & $4(66,7)$ & $2(33,3)$ & 6 & 20. Sulu köfte & $6(66,7)$ & $3(33,3)$ & 9 \\
\hline
\end{tabular}

Table 8 shows the availability of appetizers in business menus. Accordingly, humus, haydari, babagannuş and hot spicy tomato dip are found in menus. These are followed by onion salad, aubergine yoghurt, cacık, tarator, şakşuka with yoghurt, olive salad and muhammara. Less found appetizers in menus are fresh sürk salad and çökelek salad. Although there is no statistical evidence, Adana is superior in terms of meat dishes, Mersin becomes prominent with regard to appetizers. This situation is thought to stem from Mersin being a coastal city and there are more fish restaurants in the city. 
Tab. 8. Availability of appetizers in menus

\begin{tabular}{|c|c|c|c|c|c|c|c|}
\hline Appetizer Name & $\begin{array}{l}\text { Adana } \\
\text { f ( } \%)\end{array}$ & $\begin{array}{c}\text { Mersin } \\
\text { f (\%) }\end{array}$ & Total & Appetizer Name & $\begin{array}{l}\text { Adana } \\
\text { f (\%) }\end{array}$ & $\begin{array}{c}\text { Mersin } \\
\text { f (\%) }\end{array}$ & Total \\
\hline 1.Babagannuş & $22(55,0)$ & $18(45,0)$ & 40 & 10. Çökelek salad & $5(71,4)$ & $2(28,6)$ & 7 \\
\hline 2. Humus & $24(52,2)$ & $22(47,8)$ & 46 & 11. Haydari & $25(55,6)$ & $20(44,4)$ & 45 \\
\hline $\begin{array}{l}\text { 3. Hot spicy tomato } \\
\text { dip }\end{array}$ & $23(57,5)$ & $17(42,5)$ & 40 & 12. Muhammara & $15(65,2)$ & $8(34,8)$ & 23 \\
\hline $\begin{array}{l}\text { 4. Aubergine } \\
\text { yoghurt }\end{array}$ & $17(58,6)$ & $12(41,4)$ & 29 & $\begin{array}{l}\text { 13.Şakşsuka with } \\
\text { yoghurt }\end{array}$ & $14(56,0)$ & $11(44,0)$ & 25 \\
\hline 5.Zahter salad & $6(46,2)$ & $7(53,8)$ & 13 & 14. Onion salad & $23(74,2)$ & $8(25,8)$ & 31 \\
\hline 6. Olive salad & $14(63,6)$ & $8(36,4)$ & 24 & $\begin{array}{l}\text { 15. Baked onion salad } \\
\text { with pomegranate } \\
\text { molasses }\end{array}$ & $11(64,7)$ & $6(35,3)$ & 17 \\
\hline 7. Fresh sürk salad & $2(40,0)$ & $3(60,0)$ & 5 & 16. Cacık & $23(62,2)$ & $14(37,8)$ & 27 \\
\hline 8.Tarator & $13(50,0)$ & $13(50,0)$ & 26 & 17. Fava & $10(76,9)$ & $3(23,1)$ & 13 \\
\hline $\begin{array}{l}\text { 9. Red pepper with } \\
\text { walnut }\end{array}$ & $10(76,9)$ & $3(23,1)$ & 13 & 18. Şakşuka & $22(64,7)$ & $12(35,3)$ & 34 \\
\hline
\end{tabular}

Table 9 shows the distribution of olive oil included in businesses menus. Accordingly, mostly included foods in menus are dolma-sarma with olive oil and kidney beans with olive oil. They are followed by green beans with olive oil, artichoke with olive oil and imambayld 1 with olive oil. These foods are observed to be the most included ones in the menus and most preferred ones (dolma, imambayıldı and mücver) by the youth at the same time (Sanler and f., 2010c, p.927). The promotion of traditional foods to the local and foreigner tourists along with young generations for the sake of its maintainability. The least included olive oil dishes are eggplant with green lentil and stuffed turnips. 
Tab. 9. Availability of olive oil dishes in menus

\begin{tabular}{|c|c|c|c|c|c|c|c|}
\hline Food Name & $\begin{array}{l}\text { Adana } \\
\text { f (\%) }\end{array}$ & $\begin{array}{c}\text { Mersin } \\
\text { f (\%) }\end{array}$ & Total & Food Name & $\begin{array}{l}\text { Adana } \\
\text { f (\%) }\end{array}$ & \begin{tabular}{|c|} 
Mersin \\
f (\%)
\end{tabular} & Total \\
\hline $\begin{array}{l}\text { 1. Dolma-sarma with } \\
\text { olive oil }\end{array}$ & $17(68,0)$ & $8(32,0)$ & 25 & 8. Mercimek köfte & $6(60,0)$ & $4(40,0)$ & 10 \\
\hline 2. İmam bayıld 1 & $9(60,0)$ & $6(40,0)$ & 15 & $\begin{array}{l}\text { 9. Green beans with } \\
\text { olive oil }\end{array}$ & $12(70,6)$ & $5(29,4)$ & 17 \\
\hline 3. Zucchini çintme & $5(50,0)$ & $5(50,0)$ & 10 & $\begin{array}{l}\text { 10. Artichoke with } \\
\text { olive oil }\end{array}$ & $12(75,0)$ & $4(25,0)$ & 16 \\
\hline 4. Stuffed turnips & $4(100,0)$ & - & 4 & $\begin{array}{l}\text { 11. Celery with olive } \\
\text { oil }\end{array}$ & $10(71,4)$ & $4(28,6)$ & 14 \\
\hline $\begin{array}{l}\text { 5. Kidney bean with } \\
\text { olive oil }\end{array}$ & $13(56,5)$ & $\begin{array}{c}10 \\
(43,5)\end{array}$ & 23 & $\begin{array}{l}\text { 12. Leek with olive } \\
\text { oil }\end{array}$ & $11(84,6)$ & $2(15,4)$ & 13 \\
\hline $\begin{array}{l}\text { 6. Eggplant with green } \\
\text { lentils }\end{array}$ & $1(33,3)$ & $2(66,7)$ & 3 & $\begin{array}{l}\text { 13. Dry black-eyed } \\
\text { peas with olive oil }\end{array}$ & $6(66,7)$ & $3(33,3)$ & 9 \\
\hline 7. Sarımsaklı köfte & $7(77,8)$ & $2(22,2)$ & 9 & 14. Mücver & $6(66,7)$ & $3(33,3)$ & 9 \\
\hline
\end{tabular}

Table 10 shows the frequency distribution of meat dishes included in the menus of attending businesses. Accordingly, while the most include food is Adana kebab, it is followed by respectively grilled meatballs, liver kebab, steak tartar a la turca and stuffed meatballs. In the research in which familiarness of meat and meat dishes by university youth was reviewed as part of Turkish cuisine culture, the most preferred ones are respectively; steak tartar a la turca (\%98.5), stuffed meatballs (\%96.5) and farci (\%91.2) and the least known ones are oruk and lamb casserole (Şanlier and f., 2010a, p.375). Moreover, as far as it is seen a local food based situation is prevalent. Some and less known foods such as Ottoman maklube, oruk, bumbar and şırdan dolma were included relatively less. 
Tab. 10. Availability of meat dishes in menus

\begin{tabular}{|c|c|c|c|c|c|c|c|}
\hline Yemek adı & \begin{tabular}{|c|} 
Adana \\
f (\%)
\end{tabular} & $\begin{array}{c}\text { Mersin } \\
\text { f (\%) }\end{array}$ & Total & Yemek adı & $\begin{array}{l}\text { Adana } \\
\text { f (\%) }\end{array}$ & $\begin{array}{c}\text { Mersin } \\
\text { f (\%) }\end{array}$ & Total \\
\hline 1. Adana kebab & $27(60,0)$ & $18(40,0)$ & 45 & 12. Kağıt kebab & $4(30,8)$ & $9(69,2)$ & 13 \\
\hline 2. Tantuni & $2(20,0)$ & $8(80,0)$ & 10 & $\begin{array}{l}\text { 13. Tepsi (Sini) } \\
\text { kebab }\end{array}$ & $4(30,8)$ & $9(69,2)$ & 13 \\
\hline 3. Liver kebab & $18(62,1)$ & $11(37,9)$ & 29 & 14. Oruk & $1(33,3)$ & $2(66,7)$ & 3 \\
\hline 4. Bumbar stuffed & $2(100,0)$ & - & 2 & 15. Grilled meatballs & $24(63,2)$ & $14(36,8)$ & 40 \\
\hline 5. Şırdan stuffed & $1(50,0)$ & $1(50,0)$ & 2 & 16. Kadınbudu köfte & $11(68,8)$ & $5(31,3)$ & 16 \\
\hline $\begin{array}{l}\text { 6. Stuffed green pepper- } \\
\text { zucchini-eggplant with } \\
\text { chickpea }\end{array}$ & $7(100,0)$ & - & 7 & 17. Kuru köfte & $9(64,3)$ & $5(35,7)$ & 14 \\
\hline 7. Ottoman maklube & $1(100,0)$ & - & 1 & 18. Hünkar beğendi & $7(53,8)$ & $6(46,2)$ & 13 \\
\hline 8. Seasoned rice & $10(58,8)$ & $7(41,7)$ & 17 & 19. Karnıyarık & $10(66,7)$ & $5(33,3)$ & 15 \\
\hline 9. Stuffed meatballs & $15(57,7)$ & $11(42,3)$ & 26 & $\begin{array}{l}\text { 20. White bean stew } \\
\text { with meat }\end{array}$ & $12(66,7)$ & $6(33,3)$ & 18 \\
\hline 10. Steak tartar a la turca & $14(51,9)$ & $13(48,1)$ & 27 & $\begin{array}{l}\text { 21. Chick peas with } \\
\text { meat }\end{array}$ & $8(57,1)$ & $6(42,9)$ & 14 \\
\hline 11. İncik & $9(50,0)$ & $9(50,0)$ & 18 & $\begin{array}{l}\text { 22. Zucchini with } \\
\text { meat }\end{array}$ & $6(54,5)$ & $5(45,5)$ & 11 \\
\hline & & & & 23.Türlü & $6(54,5)$ & $5(45,5)$ & 11 \\
\hline
\end{tabular}

Turkish kitchen is considered as a very rich kitchen in terms of dessert variety (Kemahlığlu and Yazar, 2010, p.505). The most common desserts in Turkish kitchen are milk puddings such as baklava of which main ingredient is flour and can be made adding pistachio, walnut and nuts, kadayif and that can be made with diary products such as crema, cheese (Dönmez and f., 2009, p.36). Table 11 show the availability of desserts in menus. Accordingly, most included ones in the business menus are sütlaç, kazandibi and tel kadayif. These are followed by baklava and muhallebi. Desserts commonly consumed countrywide and not local can be said to be included more in menus. It appears that local desserts such as haytal1, bicibici and karsambaç reach costumers through smaller businesses and peddlers, from among the desserts about to be forgotten, dilberdudağı, zerde and vezirparmağ 1 are not included in menus as required. It was specified $\mathrm{n}$ researches of the familiarity with traditional desserts that; most popular desserts among university students are semolina helva, flour helva, aşure, künefe, güllaç, baklava and kazandibi (Şanlier and f., 2010b, p.935), most popular ones among local and foreigner tourists primarily baklava and respectively aşure, lokum, helva, lokma, pişmaniye, sütlaç, güllaç, hoşaf and muhallebi (Hassan and f., 2010a, p.949). It was observed that primarily karakuş, taş kadayıf, şam dessert and halka dessert are included from among the local desserts in Adana and kerebiç dessert in Mersin. 
Tab. 11. Availability of desserts in menus

\begin{tabular}{|c|c|c|c|c|c|c|c|}
\hline $\begin{array}{l}\text { Dessert } \\
\text { Name }\end{array}$ & $\begin{array}{l}\text { Adana } \\
\text { f ( }(\%)\end{array}$ & $\begin{array}{c}\text { Mersin } \\
\text { f (\%) }\end{array}$ & Total & Dessert Name & $\begin{array}{l}\text { Adana } \\
\text { f ( }(\%)\end{array}$ & $\begin{array}{c}\text { Mersin } \\
\text { f (\%) }\end{array}$ & Total \\
\hline $\begin{array}{l}\text { 1.Halka } \\
\text { dessert }\end{array}$ & $3(60,0)$ & $2(40,0)$ & 5 & 17.Tel kadayıf & $15(75,0)$ & $5(25,0)$ & 20 \\
\hline $\begin{array}{l}\text { 2.Karakuş } \\
\text { dessert }\end{array}$ & $2(66,7)$ & $1(33,3)$ & 3 & 18.Bülbülyuvası & $3(75,0)$ & $1(25,0)$ & 4 \\
\hline $\begin{array}{l}\text { 3.İrmik } \\
\text { helvası }\end{array}$ & $9(64,3)$ & $5(35,7)$ & 14 & 19.Dilberdudağı & $2(100,0)$ & - & 2 \\
\hline 4.Un helvas1 & $5(83,3)$ & $1(16,7)$ & 6 & $\begin{array}{l}\text { 20.Tulumba } \\
\text { dessert }\end{array}$ & $4(57,1)$ & $3(42,9)$ & 7 \\
\hline 5.Aşure & $7(63,6)$ & $4(36,4)$ & 11 & $\begin{array}{l}\text { 21.Ekmek } \\
\text { kadayıfı }\end{array}$ & $4(80,0)$ & $1(20,0)$ & 5 \\
\hline 6.Künefe & $8(61,5)$ & $5(38,5)$ & 13 & 22.Keşkül & $8(72,7)$ & $3(27,3)$ & 11 \\
\hline 7.Güllaç & $8(72,7)$ & $3(27,3)$ & 11 & 23.Revani & $5(55,6)$ & $4(44,4)$ & 9 \\
\hline $\begin{array}{l}\text { 8.Lokma } \\
\text { tatlis1 }\end{array}$ & $4(100,0)$ & - & 4 & 24. Karsambaç & $1(100,0)$ & - & 1 \\
\hline 9.Baklava & $10(58,8)$ & $7(41,2)$ & 17 & 25. Sütlaç & $16(59,3)$ & $11(40,7)$ & 27 \\
\hline 10.Kazandibi & $15(75,0)$ & $5(25,0)$ & 20 & 26. Muhallebi & $7(46,7)$ & $8(53,3)$ & 15 \\
\hline 11.Kerebiç & $1(11,1)$ & $8(88,9)$ & 9 & 27. Tavukgöğsü & $8(57,1)$ & $6(42,9)$ & 14 \\
\hline 12. Haytalı & $1(100,0)$ & - & 1 & 28. Kalburabastı & $3(75,0)$ & $1(25,0)$ & 4 \\
\hline 13.Şam tatlisı & $4(80,0)$ & $1(20,0)$ & 5 & 29. Şekerpare & $7(58,3)$ & $5(41,7)$ & 12 \\
\hline 14.Bicibici & $1(100,0)$ & - & 1 & 30. Şöbiyet & $2(66,7)$ & $1(33,3)$ & 3 \\
\hline $\begin{array}{l}\text { 15.Kabak } \\
\text { tatlis1 }\end{array}$ & $8(61,5)$ & $5(38,5)$ & 13 & 31. Zerde & $1(50,0)$ & $1(50,0)$ & 2 \\
\hline $\begin{array}{l}\text { 16.Taş } \\
\text { kadayıf }\end{array}$ & $7(70,0)$ & $3(30,0)$ & 10 & 32.Vezirparmağ1 & $2(100,0)$ & - & 2 \\
\hline
\end{tabular}

Table 12 shows the availability of drinks in menus. Accordingly, our traditional drink tea is the most included one in our menus. This is followed by Turkish coffee and buttermilk. This situation reflects the situation acoss the country. Drinks such as Haşlama and kaynar being available in menus though in small amounts is noteworthy. 
Tab. 12. Availability of the drinks in menus

\begin{tabular}{|c|c|c|c|c|c|c|c|}
\hline Drinks Name & $\begin{array}{l}\text { Adana } \\
\text { f (\%) }\end{array}$ & $\begin{array}{c}\text { Mersin } \\
\text { f (\%) }\end{array}$ & Total & Drinks Name & $\begin{array}{c}\text { Adana } \\
\text { f (\%) }\end{array}$ & \begin{tabular}{|c|} 
Mersin \\
f (\%)
\end{tabular} & Total \\
\hline 1. Salep & $12(44,4)$ & $15(55,6)$ & 27 & 5. Buttermilk & $33(66,0)$ & $17(34,0)$ & 50 \\
\hline 2. Haşlama/Aşlama (Licorice) & $5(100,0)$ & - & 5 & $\begin{array}{l}\text { 6. Turkish } \\
\text { coffee }\end{array}$ & $31(54,4)$ & $26(45,6)$ & 57 \\
\hline 3. Kaynar & $6(100,0)$ & - & 6 & 7. Tea & $35(59,3)$ & $24(40,7)$ & 59 \\
\hline 4. Turnip juice & $31(60,8)$ & $20(39,2)$ & 51 & & & & \\
\hline
\end{tabular}

\section{CONCLUSION AND SUGGESTIONS}

Due to the our present day, conditions and great changes, the chance of our culture being persistent is decreasing day by day (Şanlıer and f., 2008, p.1123). Changing living conditions and exposure to western culture, rapid industrialisation and urbanization, women participating working life, and their educational level increasing cause the eating habits and related appreciation habits to change (Şanlier and f., 2010c, p.925). However with the increase of local foods in menus, gastronomy tourism which is recently becoming prominent both in our country and in the region will be supported and will help these foods to survive without losing their essence and to pass on to new generations preventing them to be forgotten. The ultimate way to increase the number of tourists in the region and gastronomy tourism to accelerate across the country is the inclusion of our local foods hotels and restaurants menus and the promotion of regional cuisine ideally.

When the acquired data in the reasearch is evaluated, it is possible to reach following summary results:

1) In addition to breakfast foods popular across the country (tulum cheese, gözleme) local breakfast foods (sıkma, bazlama, çökelek and turunç jam) are also included in business menus.

2) Pastries of which familiarness by local and foreigner tourists is pretty high (mant1, water heurek) (Hassan and f., 2010a, p.949) appear to be included in the menus.

3) Regional soups (such as yüksük, tarhana, analıkızlıi ekşili köfte) are specified to be often included in business menus.

4) Appetizers with high familiarness and commonly encountered in the southern kitchen (such as humus, haydari, babagannuş, ac1lı ezme) are included in the menus.

5) It is specified that foods with olive oil (dolma-sarma with olive oil, kidney bean with olive oil) with high familiarness (Şanlıer and f., 2010c, p.927) primarily by young people are included in menus.

6) As for the meat dishes Adana kebab which has a special place in southern kitchen is the first place. Along with that other meat dishes (grilled meatballs, liver kebap, steak tartar a 
la turca, stuffed meatballs) with high familiarities (Şanlıer and f., 2010a, p.375) are specified to be included in menus.

7) Desserts with high familiarness by local and foreigner tourists (Hassan and f., 2010a, p.949) frequently consumed and not local traditional desserts (baklava, sütlaç, kazandibi, tel kadayif) are seen to be included in menus.

8) Traditional honouring drinks of Turks, tea and Turkish coffee are included in all business menus. This situation not being a regional feature, is prevalent all across the country.

It is reported that income level of tourists is an important variable in their attendance in gastronomy tourism activities, tourists with high income prefer regional and premium restaurants, take interest in local foods, buy various gastronomic products (Bekar and K1lıç, 2014, p19). That is to say, local foods can play a role for the specification of the profile of tourist mass visiting the region. Accordingly as the rate of inclusion of local foods in menus will create attraction for tourists with high income, there will be benefits in increasing this rate. Besides, promotion, advertisements, creating separate menus from business menus can be a motivation for drawing attention to the foods and thus to region.

Gastronomy tourism is one of the developing types of tourism currently. Regions which are tried to be developed by featuring local foods can increase their familiarity by creating awareness. Gastronomic variety which is one of the cultural elements ensures cooking and eating habits to be preserved and improve in regions where it turned into a touristic attraction element (Deveci and f., 2013, p.29). In our country local foods of each region differ and are varied. Tourism businesses play an important role regions drawing attention with their own cuisine cultures. In planning of these businesses' menus, ensuring local foods and drinks to certainly take place in the menu has a primary importance in making the region a preferable attraction center as a gastronomy tourism destination. Replies received to the question directed to business managers "Why do you include traditional/local foods in your menu?" are put in a good way for this argument. Because a great number of managers replied this question as "As it's our customers' demand" (40 managers) So there is a demand for local foods. For this reason, rich cuisine culture must be used as a tool for maintaining region's destination image.

Increasing the inclusion rate of local foods will create long term benefits. Namely, awareness and familiarness will turn into attention in time and this will turn into demand if proper maintaining effort is made. Thus we will get a chance to prevent some troublesome and long time-consuming local foods to be defeated by convenience food industry in a wide scale. On the other hand, it can be said that ensuring national and international familiarness will make it easy for these foods to be passed on to future generations and thus will contribute to its maintenance. Expressions of business managers as "we are including local foods in our menus for making the new visitors taste local foods, promoting our regional cuisine, protecting and maintaining our culture" support this argument. Business managers saying they don't include local foods in their menus attribute its reason to the difference in their concepts.

Prominance of some local foods in research can be interpreted as positive. However, the awareness that regional cuisine is not made up of only Adana kebab or stuffed meatballs, that there is a rich culture in the region, other local foods should also be cared about. 
Moreover, the fact that research area is close to regions such as Gaziantep and Hatay where regional cuisine is prominent must be considered an advantage, efforts for national and international integrated marketing of the region in terms of gastronomy tourism must be raised.

The fact that no class discrimination was made among businesses in the research area to obtain as much data as possible in this research aiming at reviewing the inclusion rate of local foods in menus of hotels and restaurants, is the most sigificant limitation of the reasearch. The research performed with 82 businesses in total from two cities constitutes another limitation in terms of sample size. On the other hand, struggle to sample qualitative businesses as far as possible is another limitation. In other words, places that can be defined as small or booth are not included in universe. So as for the researches to be made, there is benefit in reviewing all the restaurants regardless of their size having hygiene and cleanliness to get more generalisable results.

In sequential researches, factors affecting restaurants' traditional/local food and beverage preferences can be specified. With regard to the detected factors, elaborate interviews can be made with the ones that prefer the least or the most by mens of situation sampling. Based on these interviews, it can be set forth in detail why local foods and drinks take place less in menus and how they can be raised. Delphi studies can also be performed concerning the problems and their solutions.

\section{REFERENCES}

1. Aslan, Z.,Güneren, E., Çoban, G., ( 2014.): Destinasyon Markalaşma Sürecinde Yöresel Mutfağın Rolü: Nevşehir Örneği. Journal of Tourism and Gastronomy Studies, 2(4): 3-13.

2. Bekar, A., Kılıç, B., ( 2014.): Turistlerin Gelir Düzeylerine Göre Destinasyondaki Gastronomi Turizmi Etkinliklerine Katılımları. International Journal of Social and Economic Sciences 4 (1): 19-26.

3. Berik, N., Kahraman, D., ( 2009.): Asma Yaprağında Sardalya Balığı. II. Geleneksel Gidalar Sempozyumu, 27 -29 Mayıs 2009, Van, s: 212-215.

4. Deveci, B., Türkmen, S., Avcıkurt, C., (2013.): Kırsal Turizm İle Gastronomi Turizmi İlişkisi: Bigadiç Örneği. International Journal of Social and Economic Sciences, 3 (2): 29-34.

5. Dönmez, M., Sağdıç, O., Cankurtaran, M., (2009.): Farklı Reçetelerde Hazırlanan Peynir Helvası (Höşmerim) Üretimi. II. Geleneksel Gıdalar Sempozyumu, 2 -29 Mayis 2009, Van, s: 367-371.

6. Evren, M.,Apan, M., Tutkun, E., Evren, S., ( 2010.): Geleneksel Şekerli Türk Ürünlerinde Bozulma Etmeni Mikroorganizmalar. Adriyatik, s: 818-820.

7. Güler, S., (2007. ): Türk mutfağının değişim nedenleri üzerine genel bir değerlendirme. 1. Ulusal Gastronomi Sempozyumu ve Sanatsal Etkinlikler, 4-5 Mayis Antalya.

8. Hassan, A., Şanlıer, N., Durlu Özkaya, F., Cömert, M., Gücer, E., Konaklıŏlu, E., Pelit, E. 2010a. Yerli ve Yabanc1 Turistlerin Türk Mutfağında Yer Alan Geleneksel Hamur İşi ve Tatlıları Bilme Durumları. The $1^{\text {st }}$ International Symposium on "Traditional Foods from Adriatic to Caucasus". 15-17 April 2010, Tekirdağ, s: 948-951. 
9. Hassan, A., Şanlıer, N., Durlu Özkaya, F., Cömert, M., Gücer, E., Konaklığlu, E., Pelit, E. 2010b. Yerli ve Yabanc1 Turistlerin Türk Mutfağında Yer Alan Yemeklere İlişkin Görüşleri. The $1^{\text {st }}$ International Symposium on "Traditional Foods from Adriatic to Caucasus”. 15-17 April 2010, Tekirdağ, s: 971-974.

10. Kan, M.H., Kaynakçı, E.C., (2009.): Antik Çağdan Bugüne Anadolu Yemekleri. II. Geleneksel G1dalar Sempozyumu, 27 -29 Mayıs 2009, Van, s: 268.

11. Kemahlığlu, K., Yazar, G., ( 2010.): Güllaç Yufkası Üretimi. 1. Uluslar arası “Adriyatik’ten Kafkaslar'a Geleneksel Gidalar” Sempozyumu. 15-17 Nisan 2010, Tekirdağ. S: 505-50.

12. Kolukırık, C., Şener, T., (2010.): Geleneksel Tekirdağ Peynir Helvasının Tanitılması, Pazar Olanaklarının ve Pazarlama Stratejilerinin Değerlendirilmesi. Adriyatik: 53- 55.

13. Köten, M., Ünsal, A.S., Atlı, A., ( 2010.): İkliçe. 1. Uluslar arası “Adriyatik’ten Kafkaslar'a Geleneksel Gidalar” Sempozyumu. 15-17 Nisan 2010, Tekirdağ. S: 515-517.

14. Ulusoy, K., Karakaya, M. 2010. Sırın. Köten, M., Ünsal, A.S., Atlı, A., ( 2010.): İkliçe. 1. Uluslar aras1 “Adriyatik’ten Kafkaslar'a Geleneksel Gıdalar” Sempozyumu. 15-17 Nisan 2010, Tekirdağ. S: 527 -528.

15. Sitti, S., Hayta, M., Yetim, H., (2009.): Kayseri Mantısı: Hazırlanışı ve Kalite Nitelikleri. II. Geleneksel Gidalar Sempozyumu, 27 -29 Mayıs 2009, Van, s: 208211.

16. Şanlıer, N., Cömert, M., Durlu Özkaya, F., (2008.): Türk Mutfağındaki Geleneksel Tatlı ve Helvaları Gençlerin Tanıma Durumu. Türkiye 10. Gıda Kongresi, 21-23 May1s 2008, Erzurum, s:1123-1127.

17. Şanlıer, N., Hassan, A.T., Durlu Özkaya, F., Pelit, E., Güçer, E., Cömert, M., Konaklığlu, E. 2010a. Geleneksel Et ve Etli Yemeklerin Üniversite Gençleri Tarafindan Bilinme Durumu. The $1^{\text {st }}$ International Symposium on "Traditional Foods from Adriatic to Caucasus". 15-17 April 2010, Tekirdağ, s: 374-376.

18. Şanlıer, N., Hassan, A.T., Durlu Özkaya, F., Pelit, E., Güçer, E., Cömert, M., Konaklığlu, E. 2010a. Geleneksel Türk Yemeklerinden Tahı1, Tatlı ve Hamurişlerinin Üniversite Öğrencileri Tarafından Bilinme Durumu. The $1^{\text {st }}$ International Symposium on "Traditional Foods from Adriatic to Caucasus". 15-17 April 2010, Tekirdağ, s: 934-936.

19. Şanlıer, N., Hassan, A.T., Durlu Özkaya, F., Pelit, E., Güçer, E., Cömert, M., Konaklığlu, E. 2010c. Çorba ve Zeytinyağlı Yemeklerin Türk Mutfağındaki Yeri ve Gençler Tarafından Bilinme Durumu. The $1^{\text {st }}$ International Symposium on "Traditional Foods from Adriatic to Caucasus". 15-17 April 2010, Tekirdağ, s: 925-927.

20. Yurt, B., Yıldız, Ö., Kumlay, A.M., Küçüköner, E., (2010.): Iğdır Yöresinde Tüketilen Bazı Hayvansal Kaynaklı Geleneksel Gıdalar. 1. Uluslararası “Adriyatik'ten Kafkaslar'a Geleneksel Gidalar” Sempozyumu. 15-1 Nisan 2010, Tekirdağ. S: 358-359.

21. Zorba, Ö., Taş, C., Baytar, B., Çitfçi, G., ( 2010.): Gümüşhane Dut Pestili ve Kömesi Üretimi. Adriyatik, s: 851-852. 